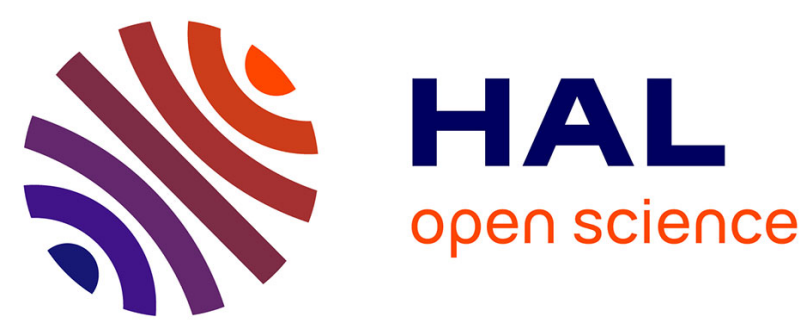

\title{
Sustainable urban logistics: Concepts, methods and information systems
}

Jesus Gonzalez-Feliu, Jean-Louis Routhier, Frédéric Semet

\section{To cite this version:}

Jesus Gonzalez-Feliu, Jean-Louis Routhier, Frédéric Semet. Sustainable urban logistics: Concepts, methods and information systems. Sustainable urban logistics: Concepts, methods and information systems, Springer, pp.i-iii, 2014. halshs-01056156

\section{HAL Id: halshs-01056156 \\ https://shs.hal.science/halshs-01056156}

Submitted on 16 Aug 2014

HAL is a multi-disciplinary open access archive for the deposit and dissemination of scientific research documents, whether they are published or not. The documents may come from teaching and research institutions in France or abroad, or from public or private research centers.
L'archive ouverte pluridisciplinaire HAL, est destinée au dépôt et à la diffusion de documents scientifiques de niveau recherche, publiés ou non, émanant des établissements d'enseignement et de recherche français ou étrangers, des laboratoires publics ou privés. 


\section{Sustainable urban logistics: Concepts, methods and information systems}

\section{Preface}

Jesus Gonzalez-Feliu, Jean-Louis Routhier and Frédéric Semet

Urban logistics is a wide studied subject. Indeed, since more than twenty years, several researchers and practitioners deal daily with different issues concerning planning and management of urban freight transport systems. Nowadays, two definitions of city/urban logistics are retained. The first is that of Taniguchi et al. [1] who define city logistics as «the process for totally optimizing the logistics and transport activities by private companies in urban areas while considering the traffic environment, the traffic congestion and energy consumption within the framework of a market economy ». The second, more related to the vision of Ambrosini and Routhier [2] and Anderson et al. [3], is not related to the notion of optimization but to organization. In this sense, we can define urban logistics as the pluridisciplinary field that aims to understand, study and analyze the different organizations, logistics schemes, stakeholders and planning actions related to the improvement of the different goods transport systems in an urban zone and link them in a synergic way to decrease the main nuisances related to it. Although the field has been studied for almost 40 years, it is only at the end of the $\mathrm{XX}^{\text {th }}$ century that we observe the main coordinated actions of research having a direct impact into practice.

Nowadays, we can observe thousands of specific actions in urban logistics, many directly issued from research programs, but not all of them are still operational. This is mainly due to the different stakeholders that are seen in urban logistics, as well as the wide variety of aims and stakes and to the consequent difficulties to pursuit collaborative actions. Public stakeholders (politicians, city planners, public transport managers, regional or national technical services) are on a collective welfare vision and aim to reduce the main nuisance attributed to freight transport, i.e. congestion, pollution, global warming and noise without penalizing urban areas and also while creating employment when possible. Private stakeholders (shippers, transport and logistics operators, retailers, wholesalers, craftsmen, real state stakeholders, tertiary activities, etc.) are on an economic efficiency vision and aim to reduce costs and/or increase service quality, of course with an eye on the environment but not as a primordial criterion. It is clear that for each stakeholder the notion of sustainability is not the same. Although all of them refer to the Kyoto protocol, the importance that they give to each of its components (economic, environmental and social) is not the same, and it is often difficult to provide a unified vision to compare proposals and solutions. Furthermore, those issues are amplified due to the high constrained environment of urban goods transport and the interaction that it makes with personal transport (although goods transport is often indicated as source of nuisance, it is proven that its inefficiency is a consequence of the nuisances personal transport have on goods transport).

In this context we think important to make the links between research and practice, and provide a general framework to help both public and private stakeholders in managing and planning urban logistics systems. This book aims to provide both a conceptual framework for urban logistics planning and management and to create a basis for deploying solutions that aim to reduce the main nuisances related to urban goods. In addition to public authorities' 
aims and goals, the book highlights the importance of private actors, and shows how supply chain management can deal with the problems of the last urban mile and its integration in global logistics chains.

The book is divided in four parts. The first aims to describe and set the current situation, not only on the (historical) viewpoint of city planners but also on that of sustainable managers. The second part proposes a set of methodological chapters, written by key authors, which aim to support decision makers in terms of understanding and simulating the current situation in terms of urban goods flows. The third part is more related to tactical planning actions, including both public and private viewpoints. The fourth part is focused on strategic planning issues, also on both viewpoints.

The first part is composed on four chapters, two related to the links of urban logistics with supply chain management, and two focused on the relations between local governance and logistics development.

In the first chapter [5], Daniel Boudouin, Christian Morel and Mathieu Gardrat present the main links between supply chain management and urban logistics, focusing on the natural interfaces between both of them: urban logistics platforms. Those links are presented from public and private sector viewpoints. A typology of urban logistics platforms is proposed, based on the structure of present and hypothetical future demand in terms of urban goods movements. Finally, the authors formulate several recommendations on new forms of organizations, technologies and governance.

If the first chapter focuses on urban logistics to see the links to global supply chain management (bottom-up), the second one has a top-down approach [6]. Joëlle Morana presents the main concepts of sustainable supply chain management and applies them to urban logistics. In this chapter, the links are not physical but organizational, and are more related to private stakeholders. The place of urban goods transport in a sustainable supply chain management process is shown, and illustrated via the example of the urban consolidation center of Padova (Italy). This example illustrates the need of collaboration among both private and public stakeholders and the importance of a sustainable thinking which do not focuses only on environmental hopes but also on economic and social facts.

The third chapter adopts clearly a public planner's perspective [7]. Erica Ballantyne and Maria Lindholm show, via an interview-based study, the issues related to including the identification of goods transport demand needs into urban plans. The authors present the similarities in the way that local authorities from Sweden, the UK, and Baltic Sea Region countries perceive urban freight problems, and discuss the relationships between local authorities and freight stakeholders. The main findings show that local authorities have begun to acknowledge freight transport more often but the issues faced by the freight industry are still not fully understood. Finally, they highlight the potential benefits of including freight stakeholders in the transport planning process, encouraging more meaningful discussions with key freight stakeholders at an early stage in the transport planning process.

Laetitia Dablanc shows in chapter 4, via a case study on the Los Angeles mega-region, the main stakes and issues of North American authorities in terms of logistics needs and platform location and development [8]. Moreover, an in-depth analysis of the logistics sprawl 
phenomena in Los Angeles allows the author to focus on the links between local governance and logistics activities deployment, especially for the jobs and tax revenues they can generate in a time of economic difficulties. She examines two cases in Los Angeles: the first is a traditionally industrial city close to downtown; the second is the sprawling community of the "Inland Empire," east of the L.A. metropolitan area. In both cases, the author observes the influence that the warehousing/logistics industry has on the economic life of working class areas, raising questions about the pros and cons of logistics activities for local communities.

The second part is centered on data production, more precisely on the methods that allow surveying, collecting, processing and/or reconstructing the information which can be needed to define and understand the current situation in terms of urban goods flows. It contains three chapters. Chapters 5 and 6 are related on survey and data collection methods, and chapter 7 on statistical methods for estimating data from current databases.

Julian Allen, Christian Ambrosini, Michale Browne, Daniele Patier, Jean-Louis Routhier and Alan Woodburn propose a wide review of survey methods that have been carried in Europe, based on the conclusions of the BESTUFS II project [9]. From survey work carried out with experts in eleven European countries, a comparison of urban freight transport data collection efforts is made to better understand what currently takes place and to identify examples of good practice. Authors observe that the extent of urban freight data collection varies significantly between the European countries, as existing urban freight data comes mainly from the disaggregation of national survey results. Finally, authors identify a set of gaps in data collection, as well as the need for greater standardization in data collection methods and in analysis and reporting of this data.

The same subject is studied by José Holguin-Veras and Miguel Jaller, who analyse characteristics and unique features of the freight system, focusing on data requirements of different modeling techniques [10]. Although both chapters refer to data collection, authors here focus on modeling and estimation, and study the roles of various data collection procedures. The analyses produce a set of findings of relevance to the design of comprehensive freight data collection frameworks for mid-size and large urban areas like those that can be seen in North America. From those findings, authors propose a modular data collection framework to support urban stakeholders' decisions concerning data collection methods depending on their needs and constraints.

Jesus Gonzalez-Feliu, Christian Ambrosini, Florence Toilier and Jean-Louis Routhier propose in chapter 7 a statistical-based modeling approach to propose a data estimation tool that can be transposed to different cities, avoiding the needs of making very costly surveys . The proposed framework needs standard inputs able to be obtained by public authorities and/or private stakeholders to make a diagnosis of urban logistics in current situations. The joint process of collecting data and modeling is described, and the different modules of the framework are presented. The authors conclude by presenting the main applications and further developments.

The third part deals with tactical planning. In other words, chapters of this part propose different methods to support stakeholders in middle-term decisions (Crainic and Laporte, 1997), i.e., at a monthly-weekly horizon. Two main subjects are studied: consolidation and time constraints. 
In chapter 8, Simona Mancini, Jesus Gonzalez-Feliu and Teodor Gabriel Crainic focus on combinatorial optimization, more precisely on vehicle routing problems [12]. The authors focus on methods related to advanced consolidation systems. The authors present the main categories of systems related to consolidation, and relate to each category a group of problems. Then they focus on optimization methods, presenting the main variants and making a critical discussion of its suitability. Finally, the authors propose a socio-economic analysis to study the leverages and limits of urban consolidation systems, based on a set of interviews.

Jesus Munuzuri and Ron Van Duin deal with the issue of access time windows [13]. First, the authors motivate the importance of access times policies, and present a panorama of Dutch cities. After that, the authors present and apply a VRP-based methodology to estimate these costs, which should be brought into the overall cost-benefit analysis of urban time constraint policies. The main notions of vehicle routing optimization with access time windows are presented, and a genetic algorithm is presented. Finally, an example of application is shown as illustration.

Finally, the last part of the book focuses on strategic planning and assessment. Chapter 10 is related to the notion of logistics pooling, which can be seen as an alternative to classical urban consolidation tactics [14]. Authors propose a framework for strategic planning and ex-ante evaluation of logistics pooling systems. First, the authors present the main concepts of logistics pooling and their applications to urban delivery services. Then, an information systems-based framework for planning and evaluation is described, from which a set of indicators are identified. To illustrate this framework, the authors present a case study from a French urban logistics pooling system.

Agostino Nuzzolo and Antonio Comi propose in chapter 11 a framework to forecast the direct effects of urban logistics measures [15]. Such effects can be internal (transportation cost variations) or external (variations of pollution, noise and road accidents). First the authors consider the shopping and restocking components of urban freight mobility and the relative actor's choices that can be influenced by city logistics measures. After that they consider the road system with its various components, and the demand models are analyzed with particular attention to shopping demand models. The model is calibrated and the possible applications are enounced.

Edoardo Marcucci and Valerio Gatta lead with the heterogeneity in retailers' choices concerning the acceptability of urban logistics measures. The authors report the result of a stated ranking exercise conducted in the Limited Traffic Zone of Rome (Italy) in 2009 focusing on retailers and their acceptability to pay for different measures concerning urban deliveries [16]. The authors make a comparison between two model specifications and study the non-linear effects for the variations of the levels of the attributes considered. The results obtained are very interesting and meaningful from a policy perspective since they show potentially differentiated effects of the policy implemented in deep contrast with the, often assumed, homogenous effect hypothesis.

Finally, Jesus Gonzalez-Feliu, Eiichi Taniguchi and Bruno Faivre-d'Arcier propose an overview on one important but little studied issue in urban logistics: that of financing and/or refunding urban logistics solutions [17]. After presenting the main refunding strategies in urban economics and relating them to urban logistics, the authors propose to analyze the potential of cost benefit analysis in urban logistics. The general method and an application to the deployment of delivery space booking systems are proposed, and results discussed. 
Finally, authors list the main fields where public-private partnerships can be applied and identify the main refunding issues related to them.

With that plethora of approaches, proposed by key authors, this book aims to give readers a basis for understanding, planning and managing urban logistics systems with the respect of the sustainability development conditions, allowing a wide variety of stakeholders a unified and pluridisciplinary overview of the main subjects concerning sustainable urban logistics.

\section{References}

[1] Taniguchi, E., Thompson, R. G., Yamada, T., \& Van Duin, R. (2001). City LogisticsNetwork modelling and Intellegent Transport Systems, Amsterdam: Pergamon.

[2] Ambrosini, C., \& Routhier, J. L. (2004). Objectives, methods and results of surveys carried out in the field of urban freight transport: an international comparison. Transport Reviews, 24(1), 57-77.

[3] Anderson, S., Allen, J., \& Browne, M. (2005). Urban logistics-how can it meet policy makers' sustainability objectives? Journal of Transport Geography, 13(1), 71-81.

[4] Crainic, T. G., \& Laporte, G. (1997). Planning models for freight transportation. European Journal of Operational Research, 97(3), 409-438.

[5] Boudouin, D., Morel, C., \& Gardrat, M. (2014). Supply chains and urban logistics platforms. In Sustainable Urban Logistics: Concepts, Methods and Information Systems (pp. 1-20). Springer Berlin Heidelberg.

[6] Morana, J. (2014). Sustainable Supply Chain Management in Urban Logistics. In Sustainable Urban Logistics: Concepts, Methods and Information Systems (pp. 21-35). Springer Berlin Heidelberg.

[7] Ballantyne, E. E., \& Lindholm, M. (2014). Identifying the need for freight to be included in local authority transport planning. In Sustainable Urban Logistics: Concepts, Methods and Information Systems (pp. 37-48). Springer Berlin Heidelberg.

[8] Dablanc, L. (2014). Logistics Sprawl and Urban Freight Planning Issues in a Major Gateway City. In Sustainable Urban Logistics: Concepts, Methods and Information Systems (pp. 49-69). Springer Berlin Heidelberg.

[9] Allen, J., Ambrosini, C., Browne, M., Patier, D., Routhier, J. L., \& Woodburn, A. (2014). Data Collection for Understanding Urban Goods Movement. In Sustainable Urban Logistics: Concepts, Methods and Information Systems (pp. 71-89). Springer Berlin Heidelberg.

[10] Holguín-Veras, J., \& Jaller, M. (2014). Comprehensive freight demand data collection framework for large urban areas. In Sustainable Urban Logistics: Concepts, Methods and Information Systems (pp. 91-112). Springer Berlin Heidelberg.

[11] Gonzalez-Feliu, J., Toilier, F., Ambrosini, C., \& Routhier, J. L. (2014). Estimated Data Production for Urban Goods Transport Diagnosis. In Sustainable Urban Logistics: Concepts, Methods and Information Systems (pp. 113-143). Springer Berlin Heidelberg.

[12] Mancini, S., Gonzalez-Feliu, J., \& Crainic, T. G. (2014). Planning and Optimization Methods for Advanced Urban Logistics Systems at Tactical Level. In Sustainable Urban Logistics: Concepts, Methods and Information Systems (pp. 145-164). Springer Berlin Heidelberg. 
[13] Muñuzuri, J., \& van Duin, J. H. R. (2014). Time constraints: the cost of sustainability. In Sustainable Urban Logistics: Concepts, Methods and Information Systems (pp. 165185). Springer Berlin Heidelberg.

[14] Morana, J., Gonzalez-Feliu, J., \& Semet, F. (2014). Urban Consolidation and Logistics Pooling. In Sustainable Urban Logistics: Concepts, Methods and Information Systems (pp. 187-210). Springer Berlin Heidelberg.

[15] Nuzzolo, A., \& Comi, A. (2014). Direct Effects of City Logistics Measures and Urban Freight Demand Models. In Sustainable Urban Logistics: Concepts, Methods and Information Systems (pp. 211-226). Springer Berlin Heidelberg.

[16] Marcucci, E., \& Gatta, V. (2014). Behavioral Modeling of Urban Freight Transport. In Sustainable Urban Logistics: Concepts, Methods and Information Systems (pp. 227243). Springer Berlin Heidelberg.

[17] Gonzalez-Feliu, J., Taniguchi, E., \& d'Arcier, B. F. (2014). Financing Urban Logistics Projects. In Sustainable Urban Logistics: Concepts, Methods and Information Systems (pp. 245-265). Springer Berlin Heidelberg. 